\title{
Evolutional Dynamism and Theoretical Model of Environmental and Operational Transformation in Vending Machine Retailing in USA and Japan
}

\author{
Hideki Takei (Corresponding author) \\ Dept. of Information Technology \& Administrative Management, Central Washington University \\ 400 E University Way, Ellensburg, WA, USA \\ Tel: 1-509-963-2617Ｅ-mail: takeih@cwu.edu
}

Torey Hewitt

Dept. of Information Technology \& Administrative Management, Central Washington University 400 E University Way, Ellensburg, WA, USA

Tel: 1-509-963-2617_E-mail: hewittt@cwu.edu

Michael Bantog

Dept. of Information Technology \& Administrative Management, Central Washington University 400 E University Way, Ellensburg, WA, USA

Tel: 1-509-963-2617Ｅ-mail: bantogm@cwu.edu

Sana Becker

Dept. of Information Technology \& Administrative Management, Central Washington University 400 E University Way, Ellensburg, WA, USA

Tel: 1-509-963-2617Ｅ-mail: beckers@cwu.edu

Received: July 10, 2010 Accepted: August 2, 2010

\begin{abstract}
Researchers have studied and discussed about the vending machine retailing by comparing marketing strategies, technological development and perspectives, location and merchandizing strategies, and cultural differences in consumer behaviors. These studies have contributed to develop retail and marketing strategies with vending machines. However, such studies have overlooked evolutional dynamism in vending machine retailing and consumer behaviors in the global markets. We found that the current movements in vending machine retailing in USA and Japan could be well explained by various theories of evolutional dynamism. We also found that such movements could be powerful enough to create new ways and environments of vending machine retailing in the countries. We could observe abrupt and drastic changes to destabilize current environments, specify elements of vending machine retailing with variety of degrees of path dependence, and draw a possible crossvergence transition to, at least, Sub-P-equilibrium.
\end{abstract}

Keywords: Retailing, Japan, Vending Machine, Path Dependence, Crossvergence

\section{Introduction}

In the modern retailing, vending machines have served as one of the most important retailing devices in almost everywhere. Still today, marketers and retailers are trying to improve retail effectiveness and efficiency via vending machines. Particularly, non-interpersonal nature of retailing has been used widely and effectively in many places where cultural and language differences exist in retailing.

Researchers have studied and discussed about the vending machine retailing by comparing marketing strategies, technological development and perspectives, location and merchandizing strategies, and cultural differences in 


\section{MInstitute Macrothin $^{\prime \prime \prime}$}

consumer behaviors. These studies have contributed to develop retail and marketing strategies with vending machines. However, such studies have overlooked evolutional dynamism in vending machine retailing and consumer behaviors in the global markets.

Therefore, our goal is to see if we can explain and hypothesize the current movements based on the evolutional dynamism theories. We chose vending machine retailing in USA and Japan in order to discuss such evolutional dynamism because the current environmental changes and businesses in the two nations seem to show significant transitions towards new ways of vending machine retailing. Therefore, if we could explain the current movements by the evolutional dynamism theories, we could hypothesize such new ways of vending machine retailing in the two nations.

\section{Vending Machine Retailing in USA and Japan}

Generally speaking, convenience of consumers and technological advancement in vending machines has been considered as critical success factors in vending machine retailing. These two will be observed particularly in location selection of the machines, payment methods, and merchandise mix. These success factors are still important and; therefore, new movements of vending machine retailing are mostly appeared in locations, payment methods, and merchandise mix (Hellmich, 2004; Yara, 2005; Freedonia Group, 2003; Paisner, 2006; Carten, Littman, Schuh, and Stavins, 2007; Hills, 2008; Guarino, 2010). We assume that such movements may create a new environment where we may observe possible transitions which may create new dynamism in the vending machine retailing.

The first success factor, locations of vending machines, has been very strong force to characterize vending machine retailing in USA and Japan. In Japan, vending machines have been located technically everywhere and this has been one of the representing images of Japanese vending machine retailing. Consumers can access to the nearest vending machines for 24 hours a day, 365 days a year (Hellmich, 2004; Yara, 2005; Freedonia Group, 2003; Paisner, 2006; Carten, Littman, Schuh, and Stavins, 2007; Hills, 2008; Guarino, 2010).

The location policy has been different in USA. Instead of putting vending machines anywhere possible, US vending retailers have taken very aggressive store-within-a-store approach. The store-within-a-store approach means that the retailers will put vending machines in stores such as malls, department stores, offices, hotels, airports, hospitals, gas stations, and schools in order to tap on consumers who are initially consumers for the "stores." This location policy was taken because of (1) security issues such as preventing vandalisms on vending machines and (2) sales inefficiency due to market size and infrastructure for the vending machine retailing. At the same time the host stores have accepted vending machines in order to improve convenience of customers (Hellmich, 2004; Yara, 2005; Freedonia Group, 2003; Paisner, 2006; Carten, Littman, Schuh, and Stavins, 2007; Hills, 2008; Guarino, 2010).

While the store-within-a-store is still very effective and no change in the location policy so far in USA, Japanese traditional location policy has been obsolescent upon strong emergence of convenience stores where consumers can purchase similar or even better merchandises or services. Especially, a numbers of store location have increased significantly, consumers tend to access to the nearest convenience store to buy similar products with wider merchandise variations and quality rather than access to the traditional vending machines (Sumitomo Trust, 2007; JVMA, 2008; Bionet, 2010). This movement is proven by the fact that convenience stores have beaten up vending machines in term of sales of products since 2001 (Sumitono Trust, 2007).

The second success factor, payment methods, has changed vending machine retailing both in USA and Japan due to current technological advancements which have increased capacity of bill acceptance and cashless transactions of vending machines. Traditionally, US vending machines are more eager to accept wider variations of payment in compare to Japan. Japanese vending machines are usually not accepting credit cards while US vending machines are more equipped with functions for credit card acceptance.

This difference seems to be caused by different preference in using credit cards as payment option. For example, US consumer behavior that they tend to use vending machines more frequently if they find credit card acceptance (Freedonia Group. 2003). Current study pointed out that sales by vending machines would increase by $50 \%$ in the USA when vending machines were equipped with functions accepting credit and debit cards (Business Wire, 2006). Such US consumer behavior will be sustained or even accelerated when modern technology has allowed vending machines to have pure cashless transaction functions (Carten, Littman, Schuh, and Stavins, 2007; Key, 2009). For example, Coke tries to lead cashless transactions by introducing the finger vein authentication (VeinID) that consumers can enjoy pure cashless and cardless transactions (Andrews, 2010). 


\section{MInstitute ${ }^{\text {Mink }}$}

While the trend towards cashless transaction has been accelerated in US markets, we have observed drastic movement towards the cashless transaction in Japan. While wide circulations of 500, 100, and 50 yen coins and pre-paid cards have still greatly helped sales via vending machines (JPO, 2010), Japanese consumers have experienced cashless and cardless transactions. It is very important to point out that Japanese consumers are shifting towards not only cashless transactions but also cardless transactions at the same time.

For example, in 2004, Japan Coca Cola started placing vending machines equipped with functions to deal with the wallet cell phone transactions. The wallet cell phone works like a debit card so that Coke will be able to secure its transactions when consumers simply put their cell phones on vending machines (GMID, 2009; Japan Coca Cola, 2010). The increasing usage of the wallet cell phone is amazing and more than 50 million Japanese have owned cell phones with the wallet cell phone functions (ACM, 2009).

In addition to the wallet cell phone, Japanese consumers have also used the cell phone credit system such as iD, and multi money system, DCMX. While we mentioned that Japanese consumers have hesitated to use credit cards for vending machine transaction, they know the convenience of pre-paid card transactions. For example, Japanese consumers have used pre-paid card type electric money such as Edy and Suica which have been also used for other transactions such as ticket-less train ticket (JCN Newswire, 2009; Japan Coca Cola, 2010). Usage of these new methods is increasing significantly. For example, users of DoCoMo's DCMX have increased from 1 million in 2006 to 10 million in 2009 (JCN Newswire, 2009).

The third success factor, merchandise mix, has not only characterized vending machine retailing but also contributed to increase the variations of locations and payment options in the two markets. Merchandize mix has been expanded for vending machines in two countries. A Japanese office worker who cannot go back to home during a busy season will be able to sleep in the office without any concerns about dress up, breakfast, drinks, clean cloths, and ties because all these necessity items can be purchased via vending machines around the office (Lewis, 2006; Yomiuri, 2006).

Similar to Japan, US consumers have been able to purchase a variety of products and services via vending machines. Guarino (2010) reported that US consumers could buy candies, juice, iPod, digital cameras, and flowers via vending machines. According to Freedonia Group's report of 2003 (Freedonia Group, 2003), the numbers of variations of merchandise and services are continuously increasing in USA.

While consumers have enjoyed various merchandises in vending machines, natures of traditional merchandises for vending machines have changed. Particularly, with technological advancements and general trends to healthier foods, vending machine retailers have tried to sell healthier and fresh foods and drinks instead of pre-cooked and chemically preserved foods (Lewis, 2006).

For example, Japanese vending machines offers not only canned coffee and Coke but also $100 \%$ juice, water, fresh vegetable, green tea, liquid energy foods, boiled eggs, and vitamin-drinks in the same machines (Lewis, 2006). Similar to Japan, US vendors have introduced healthier product lines for vending machines. For example, Aramark increased healthy food items with low-fat, low calories, and low carbohydrates in order to sell though vending machines. Frito-lay introduced baked chips as healthier chips while Nabisco introduced 100-calorie snack packs for vending machine retailing in office, hospital, and schools (Yara, 2005). Especially, US trends towards healthier foods in vending machines have been accelerated in schools where vendors have had strong pressure to sell healthier foods to kids (Hellmich, 2004; Hills, 2008).

In Japan, we can observe changes in traditionally very well sold merchandise for vending machines, cigarette. Vending machine sales of cigarettes have shown continuous declines in sales. There are two major environmental changes to explain this. First, regulatory pressure to prevent minors from smoking has introduced Taspo identification card system which will check age of consumers (Sumitomo Trust, 2007). Consumers have felt that obtaining and having Taspo ID cards are rather inconvenient so that many consumers simply do not buy the cards. As the second reason, such consumers without Taspo ID cards have found another ways to buy cigarettes at the nearest convenience stores.

\section{Evolutional Dynamism: Convergence or Crossvergence}

Convergence arguments have made to explain directions of changes in systems and structures (Bratton and McCahery, 1999; Hirata, 2003). While the convergence concepts usually discussed only convergence and divergence, As figure 1 shows, Williamson (1996) developed his comprehensive model of convergence and re-convergence which clearly pointed out an existence of a middle point on the way of convergence and re-convergence processes.

In addition to directions of convergence and re-convergence after the middle point, there has been argued a 


\section{MInstitute Macrothink $_{\text {Int }}$}

possibility of crossvergence (hybridization) direction which is a process of stabilization of the two different systems (Ralston, Gustafson, Cheung, and Rerpstra, 1993; Aoki, 2000; Aoki and Okuno, 2003; Ralston, 2008). This means that the middle point can be a new starting point to make a new and hybridized stable equilibrium as transformation process continues. Particularly, theories of evolutional dynamism have tried to explain emergence of the middle point and possible stabilization processes (Aoki, 2000; Aoki and Okuno, 2003).

The evolutional dynamism arguments by Aoki (2000) and Aoki and Okuno (2003) began explaining how the current and stabilized equilibrium can be destabilized. Then, their arguments explain transition process of the destabilized equilibrium to the temporary equilibrium on the middle point. Finally, they explained how the temporary stabilized equilibrium would start being stabilizing towards a totally new equilibrium instead of simple convergence or re-convergence. This dynamism is actually following the Darwinian concept of evolution and adaptation processes.

According to the evolutional dynamism, a stable equilibrium (a current structure) can be destabilized when there are abrupt and drastic changes in environments. Such destabilized equilibrium will start transforming to a new but unstable temporary equilibrium. Such unstable equilibrium is called as Sub-P-equilibrium where is a starting point for either re-convergence or transition towards stable new equilibrium called as P-equilibrium (Aoki, 2000; Aoki and Okuno, 2003).

There is serious uncertainty on the two different directions after the Sub-P-equilibrium because of the serious limitations of knowledge in the Sub-P-equilbrium (Aoki, 2000 and Aoki and Okuno, 2003). The transition from a stable equilibrium to the P-equilibrium via Sub-P-equilibrium has been discussed as crossconvergence (Ralston, Gustafson, Cheung, and Rerpstra, 1993; Ralston, 2008).

The path dependence theory and locked-in effects explain persistence of critical environmental elements in the stable equilibrium. This is important since we can explain and even hypothesize directions and possibilities of the crossvergence process more accurately. According to the path dependence theory, environmental elements in a stable equilibrium are characterized by a series of historical events and cultural values since the factors are created and stabilized in the history (Gilson, 2001; Licht, 2001; Rikkyo, 2003). Therefore, stabilized elements are locked-in with different strengths of persistence. The different levels of persistence are explained by three degrees of path dependence (Arthur, 1989 and 1990; Liebowitz and Margolis, 2002).

The values locked in by the $1^{\text {st }}$-degree path dependence are quire similar to the outputs in the efficient markets because the values will be always optimum or, at least, given in the markets. Consequently, systems with such values are not subjects for reforms and transformations in the current environments since the $1^{\text {st }}$-degree locked-in values will be always optimum, therefore, continuously changing as environments change (Liebowitz and Margolis, 2002).

The $2^{\text {nd }}$-degree path dependence locks in certain systems when the systems emerge and stay long enough in Sub-P-equilibrium where serious information inefficiencies exist. Therefore, while optimum values are usually very sensitive to the initial conditions and the historical events, indigenous values that are locked in by the $2^{\text {nd }}$-degree path dependence may be irrationally stabilized no matter what the historical events and the initial conditions were. As a result, the systems are stabilized but still changeable when environments become more information efficient. This will explain why systems will be drastically changed when environments become more information efficiency by drastic and abrupt environmental changes (Liebowitz and Margolis, 2002).

The $3^{\text {rd }}$-degree path dependence locks in values without historical paths and initial conditions. This values can be called as cultural values which will not be changed even if there are abrupt and drastic changes (Liebowitz and Margolis, 2002). In compare to the $2^{\text {nd }}$-degree path dependence, locked-in values by the $3^{\text {rd }}$-degree path dependence are more difficult to change so that the $3^{\text {rd }}$-degree path dependences are frequently described as unchangeable dependencies. Such values locked in the $3^{\text {rd }}$-degree path dependence may cause re-convergence.

When a stable equilibrium is destabilized by environmental changes caused by abrupt and drastic changes, remedial elements with the $2^{\text {nd }}$-degree path dependence tend to be changing forces (Liebowitz and Margolis, 2002). Since current elements with $1^{\text {st }}$-degree path dependence are and will be optimum, the elements will simply follow changes as they are throughout the crossvergence process. Even if values locked in the $2^{\text {nd }}$-degree path dependence are destabilized, convergence or crossvergence may not happen after the middle point, Sub-P-equilibrium, when values locked in by the $3^{\text {rd }}$-degree path dependence still exist. In this case, there will be re-convergence after the Sub-P-equilibrium instead of crossvergence towards P-equilibrium (Aoki, 2000; Liebowitz and Margolis, 2002). 


\section{$\Lambda$ Macrothink}

\section{Discussion}

Our first discussion will be to determine if there is any abrupt or drastic change in the vending machine retailing. If there is no such change, there is no reason to describe the transition based on the evolutional dynamism (Aoki, 2000; Aoki and Okuno, 2003). We found that there are drastic market changes which may be able to destabilized current equilibriums. For example, transits towards cashless and cardless societies have appeared by introductions and wide spreads of new payment methods such as pre-paid cards, credit cards, and multi-functional cell phones. Consumers in both countries have noticed convenient from such new payment methods. Needless to day, technological advancements in vending machines have made these diversifications of payment methods possible and almost promising.

In Japan, increasing numbers of convenience stores have created new external environments for vending machine retailing. In addition to such increasing numbers, consumers can go to the nearest convenience store in order to buy products from better merchandize mix and services. Such changing behaviors of consumers will be persisted because they have been very familiar with convenience stores.

The increasing numbers of convenience stores and changing consumer behaviors have changed location policies of vending machine vendors. While Japanese vendors used to increase numbers of vending machines in everywhere, the vendors start focusing more in the store-in-a-store approach.

Regulatory environments have changed vending machine retailing in Japan. Basically, many consumers who used to buy cigarettes from vending machines regularly have bought cigarettes at convenience stores. This is because of not only the increasing numbers of convenience stores but also feeling of troublesome with the Taspo ID. Needless to say, minors have been good customers of convenience stores for cigarettes. In USA, public opinions and governmental requests for healthier food distributions via vending machines in schools and hospitals may have changed traditional environments of the US vending machine retailing. Needless to say, technological advancements in vending machines have made these changes feasible and sustainable.

These drastic changes are seemed to be strong enough to destabilize current market equilibrium in USA and Japan. Then, our next concern will be if such destabilized equilibriums have started moving towards temporary equilibriums, Sub-P-equilibriums, in the two nations. Then, we will see if the Sub-P-equilibriums may be transformed to more stable P-equilibrium by continuous environmental changes. This means that our concern will be if there will be a crossvergence instead of re-convergence or convergence after the Sub-P-equilibrium in the two nations.

In USA, the traditional store-in-a-store approach of vending machine location is still stable and it seems to be continuously stable with the new changes. It seems like the traditional store-in-a-store approach has $1^{\text {st }}$-degree path dependence.

Wider acceptability of coins and bills are still very important while credit card acceptance is becoming a more important payment option for vending machines. While US vending machine retailers seem to add credit card acceptance functions, they have also started moving towards even cardless transaction methods such as Vein ID systems. Since credit card frauds and identity protections have been widely considered, shifting towards the cardless transaction may be another important payment option in USA. In this situation, it seems like traditional ways of transaction with coins, bills, and credit cards have been changed to add a better way of transaction. Therefore, it seems like that we lost some values in the traditional ways of transaction while we gain new values onto the traditional ways. We consider the traditional transaction methods have the $2^{\text {nd }}$-degree path dependence.

Merchandise mix has been broadened ever in both countries. Traditional merchandises for vending machine retailing have also changed to healthier and better taste products. While this looks really similar to the changing ways of transaction with the $2^{\text {nd }}$-degree path dependence, we consider that this has actually $1^{\text {st }}$-degree path dependence since retailers have aggressively added and developed more merchandises and services.

In Japan, the store-in-a-store approach and selective locations have been new location policies of Japanese vending machine vendors. For this change, we need to carefully discuss since this could cause either convergence or crossvergence transition. We know that Japanese location policy with the $2^{\text {nd }}$-degree path dependence has started moving towards the store-in-a-store location policy and the store-in-a-store approach has been locked in by the $1^{\text {st }}$-degree path dependence in the USA. When we assume that Japan will completely change the traditional vending-machine-everywhere approach to the store-in-a-store policy, this can be seen as a process of convergence towards the US location policy. However, we think it will be more logical to assume that Japan will keep the traditional policy as selective location policy while the store-in-a-store policy will be 
continuously emphasized. This means that this can be a process of crossvergence.

While Japanese wider circulations of coins and hesitations to use credit cards have made cash transactions very desirable and sustainable in Japanese markets, very high usages of pre-paid cards and cell phones have added new payment options to vending machines. Japanese consumers have been able to use pre-paid cards for train ticket purchases at vending machines. They have been also able to use cell phones as electric money at the vending machines. We can see that Japanese vending machines now have similar transaction options to USA: coins and bills, cards, and cashless-cardless. The difference here is that Japanese consumers still hesitate to use credit cards for vending machines. These Japanese changes seem to continue because of continuous usages of pre-paid cards and cell phones. This situation is very similar to one in the USA. Therefore, we assumed that there are destabilizations in the transaction methods with the $2^{\text {nd }}$-degree path dependence in Japan.

Merchandise mix has been broadened ever in Japan and this is also very similar to the experience in the US market. While Japan had had more varieties of merchandise mix in vending machines, we could observe similar merchandize mix and numbers of products items between the two markets. We also could observe a similar shift towards further product variations in the two markets. Since aggressive expansion of the merchandise mix has been and will be very critical, we consider the merchandise mix expansion will be optimum, therefore, locked in by the $1^{\text {st }}$-degree path dependence.

\section{Conclusion}

We found that the current movements in vending machine retailing in USA and Japan could be well explained by various theories of evolutional dynamism. We also found that such movements could be powerful enough to create new ways and environments of vending machine retailing in the countries. We could observe abrupt and drastic changes to destabilize current environments, specify elements of vending machine retailing with variety of degrees of path dependence, and draw a possible crossvergence transition to, at least, Sub-P-equilibrium. However, we do not know if the Sub-P-equilibrium will be transformed to be more stable P-equilibrium. We will need to continuously assess the crossvergence movement in order to hypothesize probability of the shifts towards the P-equilibrium.

\section{References}

ACM. (January 2009). Payment via wallet phone. Communications of the ACM. 52, 13.

Andrews, W. (March 2010). Finger vein vending machine: e-money at your fingertips. Japan Trends. [Online] Available: http://www.japantrends.com (May 5, 2010).

Aoki, M. (2000). Information, Corporate Governance and Institutional Diversity. NY, Oxford University Press.

Aoki, M. \& Okuno, M. (2003). Comparative Analysis of System Structure [System-no-Hikakuseido-Bunseki]. [Online] Available: http://www.geocities.co.jp/WallStreet/3015/keizaisisutemuno.txt (March 3, 2003).

Arthur, B. (1989). Competing Technologies, Increasing Returns, and Lock-in by Historical Events. Ecobomic Journal, 97.

Arthur, B. (1990). Positive Feedbacks in the Economy. Scientific American, 262.

Bionet. (2010). Japanese Vending Machines in Transition [Tenkanki-wo-mukaeta Nihon-no Jidouhanbaiki]. [Online] Available: http://www.bionet.jp/2010/01/jihanki (May 6, 2010).

Bratton, William W \& McCahery, Joseph A. (1999). Comparative Corporate Governance and the Theory of the Firm: The Case Against Global Cross Reference. Columbia Journal of Transnational Law. 38, 213..

Business Wire. (March 2006). USA Technologies Vending Machine Survey Confirms Consumers Spend Average 50\% More When Paying with Credit/Debit Cards; Validates Card Companies' Growing Investment in cashless Micro-Transactions. Business Wire. [Online] Available: http://www.encyclopedia.com/doc/1G1-143480224.html (May 6, 2010).

Carten, M., Littman, D., Schuh, S., \& Stavins, J. (2007). Consumer Behavior and Payment Choice: 2006 Conference Summary. Public Policy Discussion Papers of the Federal Reserve Bank of Boston. 7. [Online] Available: http://www.bos.frb.org/economic/ppdp/2007/ppdp0704.pdf (May7, 2010).

CDC. (September 1994). Minors' Access to Cigarette Vending Machines -- Texas. Morbidity and Mortality Weekly Report. 43, 625-627. [Online] Available: http://www.cdc.gov (May 7, 2010).

Freedonia Group. (2003). Vending Machines to 2006: Demand and Sales Forecasts, Market Share, Market Size, Market Leaders. [Online] Available: http://www.freedoniagroup.com/Vending-Machines.html (May 7, 2010).

Gilson, R.J. (2001). Globalizing Corporate Governance: Convergence of Form of Function. American Journal 
of Comparative Law.

GMID. (2009). Consumer lifestyles in Japan. Global Market Information Database. [Online] Available: http://www.portal.euromonitor.com (December 22, 2009).

Guarino, M. (March 2010). The candy machine just sold me an iPod; Popping up in military bases, airports, fast-food restaurants, and hospitals is a new kind of vending machine that offers everything from a DVD rental to a digital camera. The Christian Science Monitor.

Hellmich, N. (May 2004). School vending rated as junk. USA Today. [Online] Available: http://usatoday.com/news/health/2004-05-11-vending-machines_x.htm (May 7, 2010).

Hills, S. (October 2008). Pressure to cur calories from school vending machines. Food Navigator-USA. [Online] Available: http://www.foodnavigator-usa.com/content/view/print/221478 (May 7, 2010).

Hirata, Mistuhiro. (2003). Problems for corporate governance studies for business operations in the $21^{\text {st }}$ century. [Online] Available: http://www.mng.toyo.ac.jp/publication/keieironshu/g200103/02hirata.pdf (May 7, 2010).

Japan Coca Cola. (2010). History of Vending Machines [Jidouhanbaiki-no-Rekishi]. Japan Coca Cola, Co. [Online] Available: Http://www.cocacola.co.jp/vending/history (May 8, 2010).

JCN Newswire. (August 2009). Subscriptions to DoCoMo's credit payment service Top 10 Million. JCN Newswire.

JPO. (2010). History of Vending Machines [Jidohanbaiki-no-Rekishi]. [Online] Available: http://www.jpo.go.jp/shiryou/s_sonota/map/ippan23/4/pdf/4-2-1.pdf (May 8, 2010).

JVMA. (2008). The numbers of vending machines and annual sales in Japan [Jihanki-fukyu-daisuu oyobi Nankan-jihan-kingaku]. [Online] Available: http://222.jvma.or.jp/information/fukyu2008.pdf (May 8, 2010).

Key, P. (April 2009). USA Technologies to fit vending machines with VISA-accepting technology. Philadelphia Business Journal. [Online] Available: http://philadelphia.bizjournals.com (May 8, 2010).

Lewis, L. (July 2006). On the front line in war of vending machines. The Times.

Licht, A.N. (2001). The Mother of All Path Dependencies Toward a Cross-cultural Theory of Corporate Governance Systems. Delaware Journal of Corporate Law, 26.

Liebowitz, S.J. \& Margolis, S.E. (2002). Path Dependence, Lock-in, and History. [Online] Available: http://www.utdallas.edu/ liebowit/paths.html (April 3, 2002).

Paisner, J. (December 2006). Marketing in a Vending-Machine World. Penton Media, Inc.

Ralston, D.A., Gustafson, D.J., Cheung, F., \& Terpstra, R.H. (1993). Differences in managerial values: A study of US, Hong Kong, and PRC managers. Journal of International Business Studies, 24, 249-275.

Ralston, D.A. (2008). The crossvergence perspective: Reflections and projections. Journal of International Business Studies, 39, 27-40.

Rikkyo (2003). [Online] Available: http://www.rikkyo.ne.jp/univ/nakaeyu/ch07.htm (July 7, 2003).

Sumitomo Trust. (2007). Overview of Domestic Market for Vending Machines [Kokunai-Jidouhanbaiki-Shijo no Gaikyo]. [Online] Available: http://www.sumitomotrust.co.jp/RES/research/PDF2/673_2.pdf (May 8, 2010).

Williamson, Oliver E. (1996). The Mechanisms of Governance. NY, Oxford University Press.

Yara, S. (October, 2005). Best and Worst Vending Machines Snacks. Forbs.com. [Online] Available: http://www.forbs.com (May 8, 2010).

Yomiuri. (January 2006). Vending machines go high-tech. The Daily Yomiuri. 


\section{Macrothink}

\section{Appendix}

\begin{tabular}{|lccc|}
\hline & US Equilibrium & Hybrid & JPNEquilibrium \\
Attributes & & & \\
$\begin{array}{l}\text { Instruments } \\
\text { Incentive Intensity }\end{array}$ & ++ & + & 0 \\
Administrative Controls & 0 & + & ++ \\
$\begin{array}{l}\text { Performance Attributes } \\
\text { Adaptation A }\end{array}$ & & & 0 \\
Adaptation B & ++ & + & ++ \\
\hline
\end{tabular}

Source: Williamson (1996), Table 4.1, Pp.105. Modified by the author for this paper.

Figure 1. Williamson's Convergence and Re-convergence Model (Examples from US and Japanese Governance Model)



Aoki's 2 possible directions of transformations

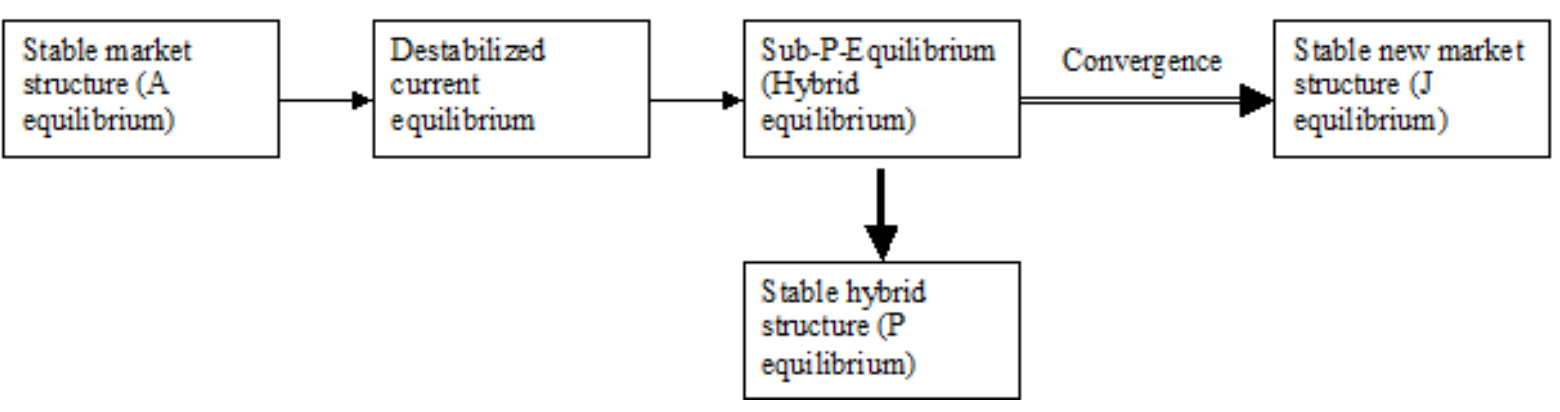

Figure 2. Directions of Transformations

Source: Williamson (1996) and Aoki (2000).

\section{Copyright Disclaimer}

Copyright reserved by the author(s).

This article is an open-access article distributed under the terms and conditions of the Creative Commons Attribution license (http://creativecommons.org/licenses/by/3.0/). 